\title{
Production Status of Citrus and Rejuvenation of Declined Citrus Orchards in Nepal
}

\author{
Binod Pokhrel* and Namrata Ghimire \\ Agriculture and Forestry University (AFU), Rampur, Chitwan, Nepal \\ *Corresponding author
}

\section{A B S T R A C T}

\section{Keywords}

Fragrance, leaves, flowers, fruits, mandarin, sweet orange, lime, lemon, grapefruits, pomelos

Article Info

Accepted:

25 May 2021

Available Online:

10 June 2021
The productivity of citrus in Nepal is not increasing in the same proportion as that of the area and one of the reasons for this is citrus decline. The citrus decline is not a specific disease but a symptomatic expression of many disorders in plants. This disorder is activated by both biotic and abiotic factors where the symptoms vary with the causes and the factors involved. The Government of Nepal has made different plans not only for the commercialization of citriculture but also for combating citrus decline. However, the history depicts the implementation phase always going weak. Other weaknesses lie in the production system and the cultural practices that are followed by the majority of Nepalese farmers. Therefore, improvement in both the production technologies and cultural practices is imminent for protecting the entire orchard from declining. Right from the seed production until the marketing of the final products, proper attention should be paid in every possible step. This paper discusses the production status of citrus and explores the options for rejuvenation of declined orchards where the data are collected via different sources.

\section{Introduction}

Citrus is a collective genus, including several varieties and species of fruits of angiosperm (flowering group) which belongs to the family Rutaceae and subfamily Aurantioideae. They are specialized by the characteristic flavor of different plant parts including leaves, flowers, and fruits. The citrus group is a rich source of vitamin $\mathrm{C}$ and its evergreen foliages and fragrance add aesthetic value to the citrus tree. Citrus plants are believed to be originated from Southeast Asia and are native to tropical and subtropical regions of Asia between $40^{\circ} \mathrm{N}$ and $40^{\circ} \mathrm{S}$ (Ashok Kumar, 2018). The majority of the citrus trees are mandarin, sweet orange, lime, lemon, grapefruits, and pomelos. These are large shrubs or medium-sized trees. These trees are best suited in a humid environment 
with good fertile soil. Citrus has been recognized as a high-value fruit crop in the mid-hills and is highly profitable than other crops (MOAC, 2011).

\section{Production status of citrus in Nepal}

Citrus is one of the most important fruit crops of Nepal in terms of area, production, productivity, and potentiality to export. Citrus shares more than $32 \%$ of the total productive area of fruit crops, nearly $22.37 \%$ of total fruit production, and $3 \%$ of total fruit export (FAO, 2011). Among citrus, mandarin orange covers nearly $21 \%$ area and about $67 \%$ of the total citrus area. Although it is widely grown in mid-hill districts of Nepal, the upper hills and Terai region are recently emerging in citrus cultivation. Out of 77 districts, citrus is grown widely in 60 districts of which 39 districts are from mid-hills (Acharya, 2016). All these mid-hill districts and 3 terai districts are producing citrus in a considerable amount. As the majority of the production is achieved from mid-hills, APP identified citrus as a high-value crop that can help to improve livelihoods and quality of mid-hill people. Mandarin orange, sweet orange, lime, and lemon are the major citrus crops while pomelo, grapefruit, sweet lime, citron, kumquat, etc are produced on small scale (Shrestha, 1999).

Province-wise details of the area of production, production, and yield are detailed in table-1 which shows that most of the area (27,952 ha) among citrus fruits is allocated for mandarin orange with the highest production (177383 MT). Auspicious climatic conditions and topography of mid-hills have favored the production of many citrus fruits. Major citrusproducing districts are Syangja, Gulmi, Tanahun, Gorkha, Dailekh, and other mid-hill districts. These districts contribute about 20\% of total citrus production in Nepal. Citrus fruits are now becoming the main potential of export in these districts nowadays. Gandaki province is the major citrus-producing region with the highest area (7,602 ha).

Despite being favorable climatic conditions and topography, citrus production in Nepal is not considerably increasing. There is fluctuation in citrus production throughout the different years. However, in the year 2019, there is a significant increase in citrus than in previous years. From the year 2012 (240,792 MT) to the year 2019 (272,620 MT), there was an increase of 13.22 percent in total production. Total production of citrus fruits has also increased continuously as in area but the average increase rate is higher than in area increase. The highest increasing rate in citrus production was found between 2016 and 2017 where a $12.74 \%$ increase in production from the previous year was recorded.

\section{Government programs to promote citriculture}

Commercialization and onset of citrus development at the government level was initiated from the early sixties by establishing citrus research stations in Pokhara (1961) and Dhankuta (1962). These two stations were working on research on citrus fruits. Thereafter, the Government of Nepal established National Citrus Development Programme (NCDP) in 1972 to promote commercial citriculture in Nepal. It focused more on the commercialization and promotion of citrus trees in some of the potential districts even though NCDP was mandated for both research and development. Many citrus nurseries were established in 1974 but planting materials were in limited supply in the required time and amount. Currently, more than 200 citrus nurseries are established for producing citrus saplings and for distribution. "Junar Production Programme" was initiated from 1980/81 by the government in Ramechhap and Sindhuli districts with the 
establishment of potential citrus orchards. These two districts are now a pioneer of junior production. As the majority of the citrusproducing areas lie in mid-hills, CADP (Commercial Agriculture development Program) was launched in 1994/95 with aim of commercialization of citrus in mid-hills. APP, which was formulated in 1995 and implemented in 1997, also concluded citrus as the main high-value crop in the mid-hills of Nepal (MOAC, 2011). Moreover, the Government of Nepal has taken initiatives of policy for promoting commercialization of citriculture by implementing national Agriculture Policy 2004 and Agri-Bussiness Promotion Policy 2007.

Although the government has taken many initiatives in past for commercial for citriculture, there is no significant increase in productivity of produce rather orchards are in the same or even worst condition (Adhikari, 2016/17). Existing citrus trees are predominantly of seedling origin and plants coexist with various seasonal inter-crops without additional plant nutrients. The absence of proper cultivation practices and long neglect has resulted in a severe decline in citrus orchards in many parts of Nepal.

\section{Factors Responsible for Citrus Decline}

Different factors that trigger citrus decline can be grouped into three groups. They are biotic, abiotic, and physiological factors.

\section{Abiotic Factors}

\section{Nutrient Imbalance}

The balance of nutrients of both the soil and plants is very important since malnutrition acts as one of the potential causes of citrus decline. Citrus can neither tolerate the excess nor the deficit of nutrients (Meena, Dutta, \& Marak, 2018). Application of NPK and foliar micronutrients is essential in citrus. But the heavy applications of fertilizers and dolomite cause a higher incidence of "declinio" (Batool, 2007). Excess of phosphorus causes crinkle rind in citrus fruits and deficiency causes defective bud formation, leaf discoloration, reduced growth, and poor fruit setting. Similarly, Potassium, Magnesium, Zinc, iron, and other micronutrients also impact adversely. Yellow areas between the large vein and on both sides of the mid-rib, bronzed leaves, chlorosis in the old leaves, poor root growth, alternate bearing, poor fruit quality, and reduced yield, sparse, bronzed and lusterless foliage, necrosis on one side of leaves, dieback of twigs, irregular yellow blotching are the symptoms that seem to enforce citrus decline.

\section{Soil-Related Factors}

Soil plays another important role in the decline of the orchard. Soil texture, salinity, organic matter content, and $\mathrm{pH}$ should be well maintained since excessive free lime, salts, presence of hardpan and lower fertility are responsible for citrus decline (Meena, Dutta, \& Marak, 2018). Excessive free lime affects permeability, aeration, root growth, and drainage while decreasing the content of iron, zinc, and manganese in the soil. Similarly, excess salt deteriorates the orchard health whereas hard pan affects the root activity and age of orchards (Chattopadhyay, 1998). For developing a healthy orchard, the ideal content of organic matter should be $2-2.5 \%$ which is believed to improve the soil texture, increase aeration, water holding capacity, and protect roots from extreme heat and cold. The best $\mathrm{pH}$ for citrus ranges from 5.5-7.5. If it is too acidic, citrus roots don't grow well; nutrients are leached out or may even become toxic. On the other hand, the higher alkalinity of soil may cause fixation of iron and zinc leading towards their deficiency in plants. 


\section{Water-Related Factors}

Proper Irrigation and drainage can be driving factors for keeping the orchard healthy. Since citrus trees are sensitive to excess moisture, irrigation should be done in such a way as to keep the soil moist, not wet (Singh, 2009).

Moreover, better drainage needs to be maintained as a high water table may also cause declination of the orchard. The poor drainage results in poor aeration, arresting the root development and causing root rot. And finally, root rot favors the Phytophthora attack resulting in dieback.

\section{Biotic (Pathological/Entomological) factors}

\section{Huanglongbing /HLB / Citrus Greening Disease}

This disease is caused by gram-negative bacteria which is polymorphic and cannot be cultured in artificial media. Yellowing, stunting, dieback of twigs; leaves are reduced with mottling, necrosis and irregular patches, poorly colored fruits with aborted seeds, reduced in size are the symptoms of citrus greening disease. Tetracycline can be injected into the trunk and spraying can also be done on the foliages to reduce the incidence of citrus greening (Bhagavati, 1989).

\section{Powdery Mildew}

This is a common disease caused by fungi. Several white patches or white powdery masses are seen on the upper surface of the leaves and twigs which consequently leads to leaf drop and dieback symptoms.

\section{Phytophthora induced Citrus Diseases}

It is one of the serious problems in Nepal. It is a soil-borne pathogen that is opportunistic and attacks whenever the susceptible host is available. Damping-off of seedling in a seedbed, root rot of grown-up seedling or trees, fruit rot, collar rot, and gummosis are the major causes of citrus decline enforced by Phytophthora.

\section{Citrus Canker}

This disease is caused by bacteria named Xanthomonas axonopodis pv. Citri. Raised necrotic patches develop on above-ground plant parts like leaves, twigs, and fruits. These bacteria enter into plants either through stomata or through wounds on the plant surface and attach to biofilms.

Different insect pests damage the orchards and some of them are found in Nepal. Citrus Psylla (Diaphorina citri) is a sap-sucking pest that secretes honey-dew which not only covers the leaves but the whole citrus trees.

It also plays a vital role in the transmission of bacteria responsible for greening. Similarly, Brown Citrus Aphid (Toxoptera citricida) feeds on newly developed terminals and withdraws a large quantity of sap along with secreting sooty mold on honey dew-covered leaves (Fateh, 2017). It is responsible for the transfer of the Citrus Tristeza Virus (CTV). Citrus Leaf Miner (Phylocnistis cytrella) damages both young and old plants by developing the serpentine silvery mines leading towards wrinkling and curling up. Infested leaves become distorted and defoliation occurs. Other insects like Citrus Thrips (Scirtothrips dosalis), Green Stink Bug (Acrosternum hilare), and Citrus Trunk Borer (Chelidonium cinctum) are also inimical for citrus trees which are the serious causes of citrus decline.

\section{Cultural Factors}

Cultural factors are human-driven and greatly impact orchard health. From irrigation to weed 
and intercropping, farmers should be conscious since they seem minor but play a major role.

The sources and methods of irrigation are very important. Defective irrigation practices ultimately cause the death of citrus (Obreza, 1993). Similarly, weeds like Loranthus feeds on the host leading towards dieback, death of infested twigs and dodder carry viruses, and feed on hosts (Meena et al., 2018). Moreover, weed roots secrete toxins affecting the growth and fruit-bearing.

The selection of good intercrops can enhance production and income. Undesirable intercrops affect the trees through exhaustion of nutrients, deterioration of soil physical properties, harboring insect pests, and disease (Atreya, 2015). Wheat, maize, sugarcane, rice, cotton deplete fertility, shade trees, and interfere the growth.

\section{Physiological Factors}

\section{Fruit Drop}

The two major causes of fruit drop are due to formation of the abscission layer at the stem end and the imbalance of certain hormones. 2,4-Dicholophenoxy Acetic Acid and 2,4,5Trichlorophenoxyacetic acid can reduce fruit drop significantly.

\section{Granulation}

Granulation is caused by the preharvest factors like high soil moisture, high temperature during fruit development, and high relative humidity. Granulation is also known as vesicle drying, kaosan, and crystallization. The juice sacs of granulated fruits become hard, dry, get enlarged, greyish with little juice content.

A higher application of nitrogenous fertilizers, high frequency of irrigation, heavy pruning, climactic factors, delayed harvesting, rootstock, fruit size, tree age, and enzymes like peroxidase, superoxide dismutase is associated with this disorder nutrient (Meena, Dutta and Marak, 2018).

\section{Splitting}

Splitting is the common disorder of sweet orange. This is caused by fluctuating physiological factors such as soil moisture, temperature, and relative humidity. Most of the splitting originates from the naval and stylar end of fruits (Ashok Kumar, 2018).

\section{Oleocellosis}

The mechanical injuries damage the oil glands and release the phytotoxic oil will cause oleocellosis. Insects attack, the incidence of hail, bruising, and contact with damaged fruits are the other causes of oleocellosis. Oleocellosis incidence is mainly observed in limes, lemons, and sweet oranges (Dhakal, 2002).

\section{Combating Citrus Decline via Improved Production Technologies}

The faulty production systems are leading to the decline of citrus orchards. Therefore, attention should be paid to the improvement in production technologies right from seed production. Collection and sowing of healthy seeds is the foremost essence to overcome citrus decline.

Healthy fully developed seeds should be collected from mother trees and treated with Captan/Thiram @ $1 \mathrm{~g} / \mathrm{kg}$ seeds to avoid infection (Knorr, 1970). Hot water treatment can also be done. Seeds of mandarin and orange should be sown in NovemberDecember while those of rootstocks are sown in September-October. The seeds are sown in plastic bags or trays with proper drainage 
holes and filled with a potting mixture of sand, soil, and well rotten FYM (1:1:1) to raise healthy seeding (ACIAR, 2010). Great care should be given during the transplantation of young seedlings. Seedlings with 4-6" height and 8-10 leaves usually after two to three weeks of sowing are ready for transplanting either in polythene bags, plastic trays, or nursery beds (Subedi, 2003). Fungicides and insecticides must be applied according to the required dosage. One of the best methods to make plant disease-resistant is budding or grafting. Disease-free, vigorous, and productive scions with matured leaves and no flowering buds should are selected for grafting. Grafted/budded plants should be kept under inspection.

\section{Combating Citrus Decline via Improved Cultural Practices}

Cultural practices can be improved for managing the orchard and preventing the decline problems. When chemicals and other practices are not in use, cultural practice becomes the easiest and efficacious way to operate.

\section{Manuring and fertilization}

All the macro and micronutrients like nitrogen, phosphorus, potassium, calcium, magnesium, zinc, iron, copper, manganese, molybdenum, and boron should be applied as needed while sulfur, sodium, and chlorine are not generally applied since these are found sufficiently in soil. The fertilizers should be applied based on recommended doses and $50 \%$ of nitrogen should be applied on the organic form while the remaining is applied in the form of inorganic fertilizers (Mandal, 2000). $10 \mathrm{~kg}$ of fertilizers should be applied in the first year and we should go on increasing the dose by $10 \mathrm{~kg}$ every year until the $10^{\mathrm{th}}$ year. Fertilizers can be applied either on the soil or foliage depending on the situation and fertilizers type.

\section{Irrigation}

Generally, citrus trees are irrigated at the interval of 15 days during winter and even shorter intervals during summer.

The three critical stages for irrigation are the flowering stage, fruit setting stage, and early stage of fruit growth. Citrus can be irrigated in 3 ways:

\section{Flood irrigation system}

Here, flood water is used to irrigate the plants. The loss of water and incidence of diseases may be the problems with this irrigation.

\section{Round Basin Irrigation System}

A basin is created and plants are irrigated via the channels that are connected to the basins.

\section{Drip irrigation system}

Compared to other systems, there is a lesser chance of water loss and disease incidence.

\section{Soil Tillage}

In Nepal, clean cultivation is favored because of lesser weeds, good aeration, moisture conservation, and protection from insect pests.

\section{Mulching}

Application of organic mulches like straw, rice hulls, dry leaves, sawdust around the tree basins helps reduce weed population, retain moisture, improve soil structure and help decompose the organic matter (FAO G., 2011). The best time for mulching in Nepal is Sept-Oct because both the moisture and organic materials are easily available at this time. While applying mulches, it should not touch the trunk of the trees as it can act as the habitat for pests. 
Table.1 Trend of production of citrus in Nepal (MOALD, 2020)

\begin{tabular}{|c|c|c|c|c|c|c|c|c|c|c|c|c|}
\hline \multirow[t]{2}{*}{ Province } & \multicolumn{3}{|c|}{ Mandarin orange } & \multicolumn{3}{|c|}{ Sweet orange } & \multicolumn{3}{|c|}{ Lime } & \multicolumn{3}{|c|}{ Lemon } \\
\hline & Area & Production & Yield & Area & Production & Yield & Area & Production & Yield & Area & Production & Yield \\
\hline 1 & 6,388 & 44,540 & 9.67 & 853 & 5,914 & 8.79 & 3,673 & 16,060 & 6.44 & 447 & 1,842 & 7.46 \\
\hline 2 & - & - & - & - & - & - & 41 & 156 & 6.18 & - & - & - \\
\hline Gandaki & 7,602 & 52,478 & 10.54 & 1,059 & 5,339 & 10.54 & 825 & 4,433 & 7.35 & 218 & 1,312 & 6.98 \\
\hline Lumbini & 3,931 & 24,139 & 11.2 & 595 & 3,239 & 9.12 & 1,951 & 8,520 & 7.52 & 29 & 139 & 9.21 \\
\hline Karnali & 3,717 & 19,063 & 9.34 & 269 & 967 & 8.47 & 795 & 2,040 & 6.12 & 113 & 516 & 6.00 \\
\hline Total & 27951 & 177383 & 61.47 & 3959 & 43060 & 59.56 & 9559 & 39579 & 48.99 & 1114 & 6056 & 49.81 \\
\hline
\end{tabular}

Fig.1 Total production of citrus over different years

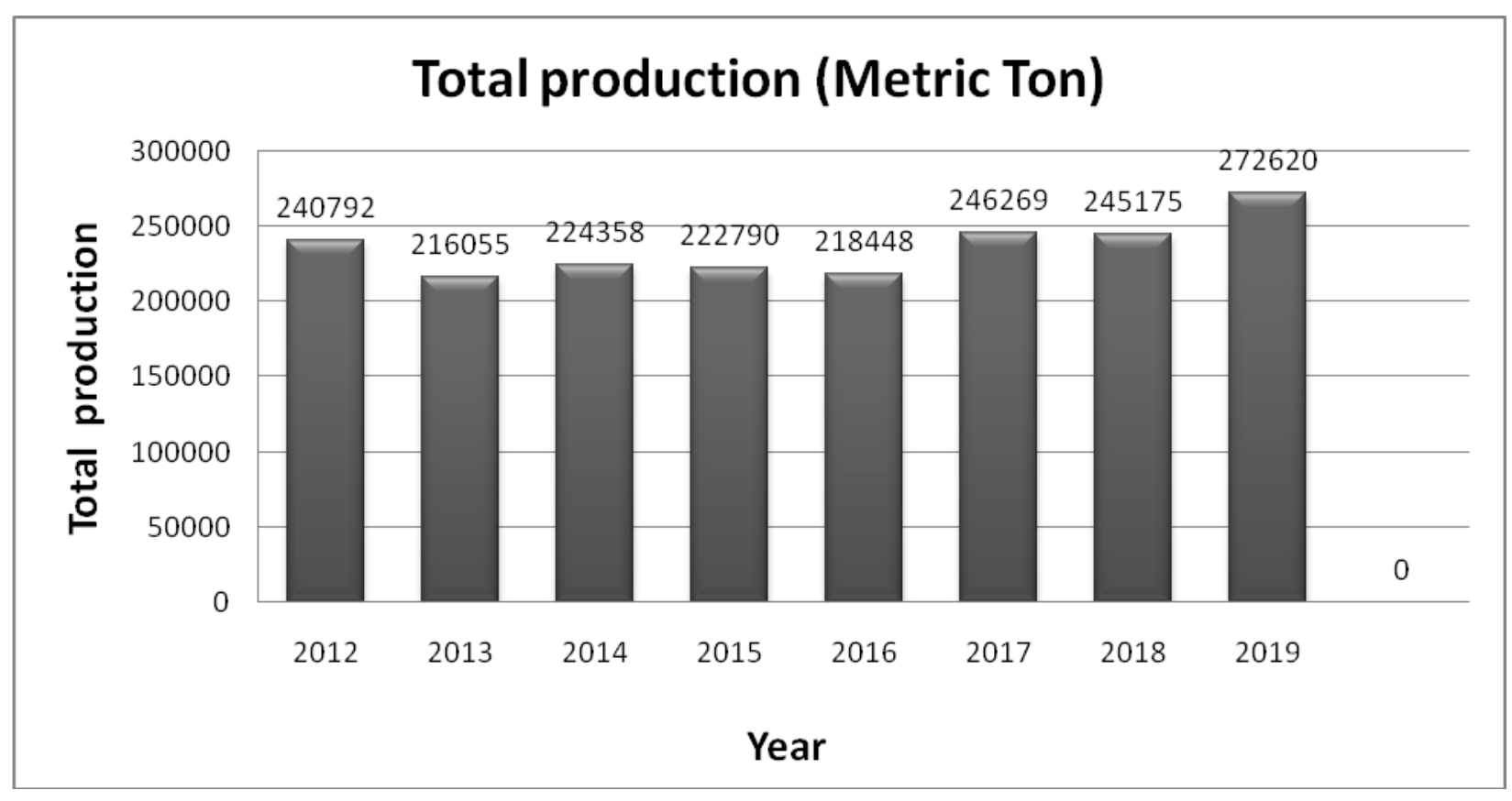




\section{Intercropping}

Intercropping should be done only in early periods and should not be done during flowering and fruiting periods. The shallowrooted and short-duration crops like pea, cowpea, French bean, soybean, papaya, pineapple, etc should be intercropped in the orchard. The exhaustive crops like maize, millet, wheat, and paddy are not desirable for intercropping.

\section{Weeding}

Having the shallow-fibrous root system, citrus is susceptible to higher weed competition. Weeds can be controlled either physically (hand pulling, cutting, hoeing, burning) or chemically (Herbicidal control).

Pre-emergence application: Diuron @ 5kg/ha

Post-emergence application: Atrazine @ $5 \mathrm{~kg} / \mathrm{ha}$

Monocot and dicot weeds: Bromocil @ 5kg/ha

Perennial grasses: Glyphosate @ 5 liters/ha

\section{Training and Pruning}

Training and pruning are done to give the tree an ideal shape and keep them healthy. Pruning is done to remove dead, diseased, and crisscross branches. Moreover, the removal of water sprouts and suckers of rootstocks is also very important. Pruning is carried out generally at the dormant stage, after harvesting, or during the late winter period.

\section{Government strategies to reduce the citrus decline}

The present policies and plans of Nepal are favorable for the development of citrus. The Master Plan for Horticulture Development
(MPHD) prepared in 1991 gave the highest priority to citrus particularly mandarin and Junar. But this plan failed to come into existence due to various difficulties. The other important policy document, which has recognized citrus as one of the main highvalue commodities and prioritized it for the mid-hills, is the Agriculture Perspective Plan (APP) (MDAP, 1992). This plan is also weak in its implementation. Based on the visions of these plans, a project proposal on the commercialization of citrus should be developed and implemented. The government of Nepal has focused to speed up the commercialization process by promoting public-private partnerships (PPP). The concept of a revolving fund should be introduced to support small farmers instead of providing subsidies.

Government is also concerned about developing collection centers in the production area. Formulation and enforcement nursery act to regulate the uncontrolled flow of nondescript/noncertified planting material across the country by introducing an internal quarantine system (Kaini, 2004). Furthermore, orchard and nursery-related strategies are also promoting from the government side. Promotion of micro-irrigation system, packaging technologies for combating citrus decline, training of technicians on virus indexing and shoot-tip micro grafting technology, and sensitization and orientation of programs in the form of the campaign are also prioritized (MOAC, 2011).

The total area of production, productive area and production of citrus fruits revealed an increasing trend but productivity is not increasing significantly. Poor management practices, little knowledge about citrus farming, and the non-accessibility of materials and technologies had led to a decline in citrus production. Different physical, biological, and physiological factors are also triggering citrus 
decline. Antiquated citrus plant replacement and pruning at regular intervals are substantial for orchard longevity. Improvement in both the production technologies and cultural practices is imminent for protecting the entire orchard from declining. Right from the seed production until the marketing of the final products, proper attention should be paid in every possible step. Therefore, rejuvenation of citrus species is also possible through proper site selection, production of quality planting materials, improved orchard management practices, better orchard management practices, and plant protection measures.

\section{References}

Acharya, B. (2016). Suntalajat Falful Kheti Prabidhi. Kirtipur, Kathmandu: National Citrus Development Program.

ACIAR, D. (2010). Production Guide for Mandarin Orchards in Bhutan. Bhutan: Australian Centre for International Agricultural Research and Department of Agriculture.

Adhikari, G. (2016/17). Reason for Citrus Orchard Decline and its management (In Nepali). Kathmandu: National Citrus Development Program.

Ashok Kumar, M. C. (2018). Citrus Decline. International Journal of Current Microbiology and Applied Sciences, 2807-2815.

Atreya, P. N. (2015). Contribution of Mandarin on Livelihood Improvement of its Growers in Parbat district. Nepalese Horticulture (10), 76-84.

Batool, A. (2007). Citrus Greening Disease A major cause of the citrus decline in the world-A Review. Horticulture Science, 159-166.

Bhagavati, K. A. (1989). Distribution of greening, Tristeza, and mosaic diseases of citrus in north-eastern states of India. Indian Phytopathology, 4 (42), 552-555.
Chattopadhyay, T. (1998). A Textbook on pomology volume-III. New Delhi: Kalyani Publishers.

Dhakal, D. (2002). assessment of Lime and Lemon Production in Nepal. Journal of the Institute of Agriculture and Animal Science (23).

FAO. (2011). Training Manual for combating Citrus Decline Problem in Nepal. Kathmandu: Food and Agriculture Organization of United Nations, Ministry of Agriculture and Cooperatives, Government of Nepal.

Fateh, F. A. (2017). Prevalence of Citrus Decline in District Sargodha. Pakistan Journal of Agricultural Sciences, 9-13.

Kaini, B. (2004). Rejuvenation of declined citrus trees. Nepalese Horticulture, 4 (1), 1-7.

Knorr, L. M. (1970). Greening disease of citrus in Nepal. 54, pp. 1092-1095. Plant Report.

Mandal, R. (2000). Weeds, Weedicides, and Weed control Principle and Practices. Bikaner, India: Agrobotanical Publisher.

MDAP. (1992). Training Manual on Citrus Fruits. Hariharbhawan, Lalitpur, Nepal: Manpower Development Agriculture Project.

Ashok Kumar Meena, Francis Dutta, Mingnam Ch. Marak and Meena, R.K. 2018. Citrus Decline. Int.J.Curr.Microbiol.App.Sci. 7(4): 2807-2815.

MOAC, M. F. (2011). Training Manual for Combating Citrus Decline Problem in Nepal. Kathmandu: Department of Agriculture, MoAC and Food and Agriculture Organization of the United Nations.

MOALD. (2020). Statistical Information on Nepalese Agriculture 2075/76 [2018/19]. Singha Durbar, Kathamandu, Nepal: Planning and development cooperation coordination 
division, Ministry of Agriculture and Livestock Development, Government of Nepal.

Obreza, T. (1993). Citrus fertilizer management on calcareous soils. Institute of Food and Agricultural Sciences, University of Florida.

Shrestha, P. A. (1999). Development and Outlook of Citrus Industry in Nepal. Kathmandu, Nepal: Nepal Horticulture
Society.

Singh, D. (2009). Influence of Integrated nutrient management on Quality protein maize productivity and soils of Southern Rajasthan India. Journal of Agricultural Sciences, 1020-1022.

Subedi, F. (2003). Integrated Citrus Management. Rampur, Chitwan, Nepal: Institute of Agriculture and Animal Science.

\section{How to cite this article:}

Binod Pokhrel and Namrata Ghimire. 2021. Production Status of Citrus and Rejuvenation of Declined Citrus Orchards in Nepal. Int.J.Curr.Microbiol.App.Sci. 10(06): 671-680. doi: https://doi.org/10.20546/ijcmas.2021.1006.074 